\title{
THE RELATIONSHIP BETWEEN READINESS PROGRAM OFFICER AND THE IMPLEMENTATION OF THE TB-DM COLLABORATION PROGRAM AT SEMARANG COMMUNITY HEALTH CENTER, CENTRAL JAVA
}

\author{
Dea Amarilisa Adespin, Hari Peni Julianti, Aras Utami, \\ Diah Rahayu Wulandari, Arwinda Nugraheni
}

Lecturer, Public Health Departement, Universitas Diponegoro

\begin{abstract}
Background: Tuberculosis (TB) is a national health problem both in the world and in Indonesia. Diabetes mellitus (DM) is a comorbid disease that contributes to $15 \%$ of TB cases in the world. In an effort to eradicate TB, the government has launched a TB-DM collaboration program in every health facility. This study aimed to determine the relationship between readiness program officer and the implementation of the TB-DM collaboration program at Semarang Community Health Center, Central Java.

Subjects and Method: This study was an observational study with a cross-sectional design conducted at community health center, Semarang. A sample of 37 TB service providers. The data were collected by questionnaire and in-depth interview. The data was analysed by Chisquare.

Results: A total of $71.6 \%$ (53 respondents) of 74 respondents have implemented the TB-DM collaboration program well. As many as $87.7 \%$ (65 respondents) have satisfactory readiness in implementing the TB-DM collaboration program. Readiness and implementation of the TBDM collaboration program were significantly related $(\mathrm{p}<0.001)$.

Conclution: The readiness of officers and the implementation of the TB-DM collaboration program are mostly good, and have a close relationship.
\end{abstract}

Keywords: TB, DM, Collaboration, implementation

Correspondence:

Dea Amarilisa Adespin. Public Health Departement, Universitas Diponegoro. Jl. Prof. Soedarto No.1269, Tembalang, Semarang, Central Java 50275

The $7^{\text {th }}$ International Conference on Public Health Solo, Indonesia, November 18-19, 2020|336 https://doi.org/10.26911/the7thicph.04.21 